\title{
Variation in Wound Healing and Resistance to Leucostoma persoonii in Peach Derived from Embryo Culture
}

\author{
Alan R. Biggs ${ }^{1}$ \\ West Virginia University, Kearneysville Tree Fruit Research and Education \\ Center, P.O. Box 609, Kearneysville, WV 25430
}

\author{
Neil W. Miles ${ }^{2}$ \\ University of Guelph, Horticultural Research Institute of Ontario, Victoria Avenue North \\ 4890, Vineland Station, Ontario, Canada, LOR 2E0
}

Additional index words. Prunus persica, peach canker, valsa canker, tissue culture

In vitro culture of Prunus persica (L.) Batsch, has been carried out by a number of investigators. One of the most common and successful techniques for this species uses excised meristems and shoot tips that are grown and multiplied on a number of complex media (Fiorino and Loreti, 1987; Hammerschlag, 1982; Hammerschlag et al., 1987; Morini and Concetti, 1985; Parfitt and Almehdi, 1986; Skirvin et al., 1979). Other researchers have developed regeneration systems for Prunus spp. with embryo cultures (Kester and Hesse, 1955, embryo-derived callus cultures (Hammerschlag, 1986; Hammerschlag et al., 1985; Meng and Zhou, 1981), and root callus cultures (Druart, 1980). Hammerschlag (1986) provided an extensive and detailed list summarizing all types of tissue culture techniques used for in vitro culture of $P$. persica and related species. Tissue culture and selection of plantlets can be one route to obtaining novel genetic material with increased pathogen resistance. For example, toxin-selected (Hammerschlag, 1988) and nonselected (Hammerschlag, 1990) embryo callus cultures of peach have produced plantlets with increased levels of resistance to the bacterial spot pathogen Xanthomonas campestris pv. pruni.

The peach canker fungi, Leucostoma persoonii and L. cinctum are the major biotic factors limiting peach production in the northern portion of the temperate fruit zone. Because peach cultivars that are immune or highly resistant to the peach canker fungi have not been identified, the goal of the present study was to evaluate regenerate peach trees produced by somaclonal selection as a source of novel genetic material with increased resistance to the peach canker fungi. The objective of this study was to determine if field-grown peach regenerates expressed somaclonal variation in wound healing characteristics that have

Received for publication 29 Oct. 2004. Accepted for publication 15 Dec. 2004. Appreciation is extended to Ken Slingerland for technical assistance. This project was funded in part by the Ontario Ministry of Agriculture and Food and the Ontario Tender Fruit Producer's Marketing Board.

${ }^{1}$ Professor. To whom requests for reprints should be addressed.

${ }^{2}$ Research horticulturist. been associated with increased resistance to Leucostoma spp.

Plant material. Plant material was obtained as described in Svircev et al. (1993). Briefly, embryos from the cultivars 'Babygold 5', 'Harbrite', and 'Harrow Diamond' were obtained from 4-year-old, field-grown peach trees at the Victoria Farm, University of Guelph, Ontario, Canada. Trees from which seeds were to be collected were enclosed in muslin tents during the bloom period to ensure a high proportion of self-pollination. Average date of full bloom was May 11.

Tissue culture. Peach seeds were excised from the green fruit, sterilized in a solution of $0.5 \%$ sodium hypochlorite ( 5 to $10 \mathrm{~min}$ ), and washed three times in sterile distilled water. To obtain callus with the highest totipotency, only embryos with a percent fill of 2.5 to 3.5 were used. Embryos were removed from the seeds, wounded and cultured to produce rooted plantlets as described by Hammerschlag et al. (1985) and Svircev et al. (1993).

Plantlets with roots were transferred to a 6 -cm peat pot ( 2 foam : 1 peat : 1 soil) and acclimated in a mist chamber maintained at 23 to $28^{\circ} \mathrm{C}$ with a $16-\mathrm{h}$ photoperiod. Plantlets were exposed to mist for $6 \mathrm{~s} / 64 \mathrm{~min}$ for $2 \mathrm{~d}, 4$ $\mathrm{s} / 64 \mathrm{~min}$ for $5 \mathrm{~d}, 4 \mathrm{~s} 2$ to 3 times/day for $7 \mathrm{~d}$, and finally no mist for $7 \mathrm{~d}$. Acclimated plants were then transferred to a greenhouse bench with supplemental lighting, water and fertilizer $\left(1 \mathrm{~N}-1 \mathrm{P}-1 \mathrm{~K} 50 \mathrm{mg} \cdot \mathrm{L}^{-1}\right.$ for 3 weeks then 100 $\mathrm{mg} \cdot \mathrm{L}^{-1}$ for $2 \mathrm{wk}$ ) as needed. The 15 - to 30 $\mathrm{cm}$-tall plants were then forced into dormancy under ambient light conditions and 5 to $10^{\circ} \mathrm{C}$ for $30 \mathrm{~d}$ and stored at $1{ }^{\circ} \mathrm{C}$ in a refrigerated storage for $90 \mathrm{~d}$. On $1 \mathrm{Apr}$., the plants were returned to the greenhouse $\left(15\right.$ to $20^{\circ} \mathrm{C}$ and ambient light and photoperiod), transferred to $12-\mathrm{cm}$ pots after 2 weeks, fertilized after 4 weeks $\left(50 \mathrm{mg} \cdot \mathrm{L}^{-1} 1 \mathrm{~N}-1 \mathrm{P}-1 \mathrm{~K}\right)$ and then acclimated to field conditions for 7 to $14 \mathrm{~d}$ in an exterior site protected from winds. At the time of planting, regenerated plants were 45 to $75 \mathrm{~cm}$ in height. To increase the numbers of plants for the replicated field study, the original regenerate plants (17 from 'Harbrite', 6 from 'Harrow Diamond', and 5 from 'Babygold 5') were grown in the field for 3 years and then bud wood was taken and grafted onto 'Halford' rootstock according to standard procedure and grown in the field for 2 years. Budwood from parent trees and cultivars and selections of known suberin accumulation rate ('Earlired', 'Redhaven', and V68101) were propagated similarly. Five plants were propagated from each somaclonal regenerate plant, each parent plant, and each cultivar or selection of known suberin accumulation.

Field and laboratory study. Due to the unbalanced design of the study because of the variable numbers of regenerates from the three cultivars, propagated trees were planted in groups of five in a haphazard arrangement. Trees were spaced at $2.5 \times 4.0 \mathrm{~m}$ and were grown at the Victoria Farm with standard cultural practices. In early June of the fourth year after planting, woody tissue from the previous year's growing season was wounded with a 7-mm-diameter cork borer to the depth of the xylem. Fourteen days later, the margin of the healing wound was sampled with a cork borer and the tissue placed in fixative, dehydrated, embedded in paraffin, and sectioned with a rotary microtome as described previously (Biggs and Miles, 1988). Suberin measurements were made with fluorescence microscopy (Biggs and Miles, 1988). Slides were coded so that the histotechnologist was blind to the specimen identity. Further data about the anatomy of wound-related tissues were collected from these samples: total thickness of suberized tissues, including primary lignosuberized tissue and new phellem; the mean number of cells in the new phellem; and the mean suberized cell thickness (calculated as total thickness/number of cells). All measurements were made in the outer cortex just internal to the original phellem.

Branches from the previous year's growth were collected from the same orchard used in the field experiments. Segments were prepared by removing $16-\mathrm{cm}$ lengths from the apical and basal ends of the branches; the remaining branch was cut into 14-cm-long segments with any leaves removed. The segments were placed in a plastic container, along with moistened absorbent paper to maintain high relative humidity. Fifteen segments were prepared for each of 9 treatments, 10 to be inoculated with the pathogen and 5 to remain noninoculated. Each segment was wounded through the bark to the xylem in the internode region, midway along the segment with a 4-mm-diameter cork borer. The wounded bark disk was discarded. Wounds were inoculated with mycelium of $L$. persoonii and covered with Parafilm. The lid was placed on the container, which was placed in a $21^{\circ} \mathrm{C}$ incubator in the dark for $72 \mathrm{~h}$, after which the Parafilm was removed. Canker length was measured along the longitudinal axis of the stem $10 \mathrm{~d}$ after inoculation. Data from the histological study were analyzed with the SAS General Linear Models (GLM) procedure assuming a random effects model and sums of squares for unequal cell sizes. Data from the pathogen inoculations were analyzed with the SAS analysis of variance (ANOVA) procedure.

The regenerate plants from 'Babygold 5' and 'Harrow Diamond', but not 'Harbrite', 
Table 1. Suberin autofluorescence intensity $(\mathrm{mV})$, number of suberized cells, thickness of the suberized layer $(\mu \mathrm{m})$, length of callus growth over the wound surface, and canker length following inoculation with Leucostoma persoonii from peach regenerants, parent cultivars, and standard cultivars and selections

\begin{tabular}{|c|c|c|c|c|c|}
\hline $\begin{array}{l}\text { Plant } \\
\text { material } \\
(\text { total no. examined })^{z}\end{array}$ & $\begin{array}{l}\text { Autofluorescence } \\
(\mathrm{mV})^{\mathrm{y}}\end{array}$ & $\begin{array}{l}\text { Suberized } \\
\text { cells } \\
\text { (no. })^{\mathrm{y}}\end{array}$ & $\begin{array}{l}\text { Suberized } \\
\text { layer } \\
\text { thickness } \\
(\mu \mathrm{m})^{\mathrm{y}}\end{array}$ & $\begin{array}{l}\text { Callus } \\
\text { generation } \\
(\mu \mathrm{m})^{\mathrm{y}}\end{array}$ & $\begin{array}{l}\text { Canker } \\
\text { length } \\
(\mathrm{mm})^{\mathrm{w}}\end{array}$ \\
\hline Harbrite regenerants (85) & $5.9 \mathrm{~cd}^{\mathrm{x}}$ & $3.0 \mathrm{cde}$ & $49.4 \mathrm{~b}$ & $630.4 \mathrm{bcd}$ & $17.3 \mathrm{bc}$ \\
\hline Harrow Diamond regenerants (30) & $6.6 \mathrm{c}$ & $3.3 \mathrm{bcd}$ & $52.2 \mathrm{~b}$ & 540.2 cde & $18.3 \mathrm{~b}$ \\
\hline Harrow Diamond parents (5) & $7.8 \mathrm{~b}$ & $3.4 \mathrm{bc}$ & $50.9 \mathrm{~b}$ & $428.9 \mathrm{e}$ & $12.6 \mathrm{c}$ \\
\hline Babygold 5 regenerants $(25)$ & $5.0 \mathrm{de}$ & $2.8 \mathrm{de}$ & $46.7 \mathrm{~b}$ & $696.5 \mathrm{bcd}$ & $17.1 \mathrm{bc}$ \\
\hline Redhaven (moderate suberin standard) (5) & $5.9 \mathrm{~cd}$ & $3.2 \mathrm{bcd}$ & $52.8 \mathrm{~b}$ & $504.2 \mathrm{de}$ & $14.5 \mathrm{bc}$ \\
\hline V68101 (high suberin standard) (5) & $9.0 \mathrm{a}$ & $5.1 \mathrm{a}$ & $76.0 \mathrm{a}$ & $936.7 \mathrm{a}$ & $12.6 \mathrm{c}$ \\
\hline
\end{tabular}

${ }^{2}$ Trees arranged in a randomized complete block design with single-tree replicates in five blocks.

${ }^{y}$ Autofluorescence intensity measured over a circular area with $272 \mu \mathrm{m}$ diameter, each measured area contained about 100 cells. Nonwounded bark autofluorescence intensity $=0$. Number of suberized cells, thickness of suberin layer, and callus growth determined in cross section in outer bark cortex immediately internal to the original periderm.

${ }^{x}$ Letters denote significant differences among means according to the Waller-Duncan $\mathrm{k}$ ratio $t$ test $(P \leq 0.05)$.

${ }^{w}$ Mean length of 10 cankers on excised stem pieces.

had reduced suberin autofluorescence intensity relative to their respective parent cultivars (Table 1). Previous research with peach cultivars and selections and the peach canker pathogens has demonstrated a significant correlation between suberin autofluorescence intensity and resistance to L. persoonii (Biggs and Miles, 1988). In the inoculation trials, we demonstrated statistically increased disease severity on regenerate plants of 'Harrow Diamond' compared to the parent cultivar, but this was not observed with 'Babygold 5' (Table 1). Interestingly, regenerate plants from 'Harbrite', but neither those from 'Babygold 5' nor those from 'Harrow Diamond', exhibited decreased numbers of suberized cells. Suberized layer thickness and callus regeneration were similar between regenerates and parent cultivars (Table 1). Earlier work demonstrated that overall suberin autofluorescence intensity and disease resistance are not correlated with numbers of suberized cells, suberized layer thickness, or rate of callus regeneration at wounds (Biggs and Miles, 1988). It is concluded that the regenerate plant system for peach is unlikely to provide plant material with increased suberin accumulation and the associated disease re- sistance that it confers to the fungi that cause peach canker disease.

\section{Literature Cited}

Biggs, A.R. and N.W. Miles. 1988. Association of suberin formation in uninoculated wounds with susceptibility to Leucostoma cincta and L. persoonii in various peach cultivars. Phytopathology 78:1070-1074.

Druart, P. 1980. Plantlet regeneration from root callus of different Prunus species. Scientia Hort. 12:339-342.

Fiorino, P. and F. Loreti. 1987. Propagation of fruit trees by tissue culture in Italy. HortScience 22:353-358.

Hammerschlag, F. A. 1982. Factors affecting establishment and growth of peach shoot tips in vitro. HortScience 17:85-86.

Hammerschlag, F.A. 1986. Peach (Prunus persica L. Batsch), p.170-183. In: Y.P.S. Bajaj (ed.). Biotechnology in agriculture and forestry. vol. 1 . Trees. Springer-Verlag, Berlin-Heidelberg.

Hammerschlag, F.A. 1988. Selection of peach cells for insensitivity to culture filtrates of Xanthomonas campestris pv. pruni and regeneration of resistant plants. Theor. Appl. Genet. 76:865-869.

Hammerschlag, F.A. 1990. Resistance responses of plants regenerated from peach callus cultures to Xanthomonas campestris pv. pruni.J.Amer. Soc.
Hort. Sci. 115:1034-1037.

Hammerschlag, F.A., G.R. Bauchan, and R. Scorza. 1985. Regeneration of peach plants from callus derived from immature embryos. Theor. Appl. Genet. 70:248-251.

Hammerschlag, F.A., G.R. Bauchan, and R. Scorza. 1987. Factors influencing in vitro multiplication and rooting of peach cultivars. Plant Cell, Tissue Organ Cult. 8:235-242.

Kester,D.E. and C.O. Hesse. 1955. Embryo culture of peach varieties in relation to season of ripening. Proc. Amer. Soc. Hort. Sci. 65:265-273.

Meng, X. and W. Zhou. 1981. Induction of embryoid and production of plantlets in vitro from endosperm of peach. Acta Agr. Univ. Peking 7:95-98.

Morini, S. and S. Concetti. 1985. In vitro propagation of P.S.B2 peach rootstock. Acta Hort. 173:205-211.

Parfitt, D.E. and A.A. Almehdi. 1986. In vitro propagation of peach: II. A medium for in vitro multiplication of 56 peach cultivars. Fruit Var. J. 40:46-47.

Skirvin, R.M., M.C. Chu, and H. Rukan. 1979. Tissue culture of peach, sweet and sour cherry and apricot shoot tips. Proc. Annu. Mtg. Ill. State Hort. Soc. 113:30-38.

Svircev, A.M., A.R. Biggs, and N.W. Miles. 1993. Peach regeneration from callus derived from embryos of selected cultivars. Fruit Var. J. 47:13-18. 